\title{
Journey to the East: A Review of Hollywood's Film Localization Efforts for China's Film Market
}

\author{
$\mathrm{Xu}$ Song \\ Correspondence: Xu Song, Communication Studies Program, School of Arts and Humanities, Stockton University, \\ Galloway, NJ, USA.
}

Received: November 16, 2018

Accepted: November 30, 2018 Online Published: December 12, 2018

doi:10.11114/ijecs.v2i1.3872

URL: https://doi.org/10.11114/ijecs.v2i1.3872

\begin{abstract}
The film market of China has been growing rapidly and is now the world's second largest film market. Hollywood studios have been sending transnational films to China to receive additional revenues. This research investigates the three channels (i.e., flat-rate buyouts, co-productions, and revenue-sharing titles) through which Hollywood studios can enter their films in China's film market and reviews the China-focused localization efforts that Hollywood studios have made to appeal to China. The review findings show that exporting Hollywood films to China as revenue-sharing titles has become the favorite approach for major Hollywood studios to gain additional revenues. To improve revenue-sharing films' box-office performance, localization efforts of Hollywood studios are executed throughout a film's theatrical life cycle, from a film's planning and production stages to its distribution, promotion, and exhibition stages. Implications and suggestions as to how Hollywood studios can further utilize film localization efforts to enhance box-office success in China are also discussed in the present study.
\end{abstract}

Keywords: Hollywood films, flat-rate buyouts, Hollywood-China, co-productions, revenue-sharing films, film localization, China's film market

\section{Introduction}

Hollywood has been exporting films as cultural products to the global market for decades. For today's Hollywood studios, China appears to be one of the most important global film markets. Indeed, the film market in China has been growing rapidly in recent years. China has already become the largest global film market outside North America (Mayyasi, 2016). As more than ten new cinema screens are being built in China every day (Verrier, 2015), China is predicted to surpass the U.S. and become the world's biggest film market by 2020 (Child, 2012; Xinhua, 2017). As the film market in China keeps developing and booming, Hollywood studios are taking the opportunity to gain extra revenues by sending a significant number of high quality film productions to China on a yearly basis. Generally, Hollywood films have been doing well in China's film market. For example, Hollywood films contributed 38.4 percent to China's box office in 2015 (Brzeski, 2015). Imported foreign films (with the vast majority being Hollywood made) claimed 41.7 percent of China's total box office revenue in 2016 (Brzeski, 2017) and accounted for 46 percent in 2017 (Brzeski, 2018).

As the relationship between Hollywood and China gains prominence and priority among Hollywood major studios, it is important to investigate the channels through which Hollywood studios can enter their films in China's film market to generate revenues and to review the China-focused efforts that Hollywood studios have made (and can make) to bypass the cultural differences and boundaries to help Hollywood films achieve box-office success in China. This research aims to discover the answers to the following research questions: 1) How can Hollywood studios enter their films in China's film market in order to receive revenues? 2) What film localization efforts have Hollywood studios made to support their films' box-office performance in China? and 3) What other efforts should Hollywood studios consider making to secure their films' success in China's film market? The answers to these research questions will help to present a detailed portrayal of the dynamics between Hollywood and China's film market, which may be of interest to film studies researchers. Film producers and professionals may find this research insightful in that it provides implications and suggestions as to how further film localization attempts can be implemented to boost Hollywood films' box-office success in China. 
To answer the proposed research questions, the present research conducted in-depth reviews as the investigative method. Real-world examples, factual evidence, descriptive data, and relevant research findings were collected from multiple credible sources of information (e.g., journal articles, media reports, government documents, and books on film studies, etc.) and were synthesized to support the review findings, implications, and suggestions. The review structure and components are described at the end of each beginning paragraph of the following three sections to guide the readers and assist their understanding of the provided information.

\section{Enter China's Film Market}

Sending films to China is a good strategy for Hollywood studios to optimize their films' revenue potential. Indeed, Chinese market can highly affect the U.S. media industry (Kokas, 2017). Given that China has become the most lucrative film market outside North America, Hollywood studios have been sending their films to China in the hope of extending their films' theatrical life cycle and generating additional revenues in today's profit-driven film market. In general, Hollywood studios can enter their transnational films to China's film market through three channels: 1) selling a film to Chinese media company at a flat rate, 2) co-producing a film with a Chinese film-making company, and 3) exporting a film as a revenue-sharing title (“China's Film Industry", 2016; Kokas, 2017; O'Connor \& Armstrong, 2015). The following review introduces each of the three channels, explains the details and conditions, and discusses the advantages and disadvantages by presenting facts, data, and examples extracted from the literature.

\subsection{Flat-Rate Buyouts}

Flat-rate movies are also called buyout films. Hollywood studios sell their movies at a flat rate to Chinese media companies. Although flat-rate movies have their own quota and are not subject to the annual import quota of 34 revenuesharing foreign films, they are not a popular option for Hollywood studios ("China's Film Industry", 2016; Kokas, 2017). Once the studio sells a movie to a Chinese company at a flat rate, the studio usually cannot receive additional revenue from the movie's box office gross in China (“China's Film Industry", 2016; O'Connor \& Armstrong, 2015), though sometimes the studio and movie producers may negotiate to receive part of the box office revenue (Kokas, 2017; also see Papish, 2017).

Buyout films are usually B-level or lower films (Kokas, 2017). Small or medium production films usually cost less to produce and do not have the huge pressure in terms of box-office revenues that big-budget blockbusters have. That makes flat-rate films worthwhile. Some flat-rate Hollywood films have received box-office success in China. For example, Sony Pictures' Resident Evil: The Final Chapter, which was imported as a flat rate buyout/revenue sharing hybrid film (Papish, 2017), grossed about $\$ 160$ million in China while only collecting \$26.8 million in North America (Barnes, 2017). Although flat-rate movies need to receive approval for screening in China, Hollywood studios would generally be able to make their flat-rate movies pass censorship by re-editing the storyline and deleting certain scenes. In addition, after the import quota for revenue-sharing foreign films is reached in China, Hollywood studios may decide to sell the wait-listed blockbusters and small or middle-range production films as flat-rates to China to make additional revenues.

\subsection{Hollywood-China Co-productions}

Hollywood studios may also receive additional revenues from China through co-productions. However, there are strict policies regulating whether or not a film will be recognized as a co-production. Collaborating with Chinese media companies in a film production does not automatically make the movie a co-production; neither does Chinese companies' investment. To qualify as an official Hollywood-China co-production, a film needs to include considerable Chinese elements, one third of the film needs to be shot in China, and a significant portion of the cast and crew must be Chinese professionals (e.g., at least one third of the lead actors/actresses must be Chinese) (Brzeski \& Roxborough, 2017; "China's Film Industry", 2016).

Co-produced films are not subject to the 34 foreign film import quota because they are not traditionally considered as foreign films (Kokas, 2017; O'Connor \& Armstrong, 2015). This also means co-produced films will have no distribution block-out dates which are usually imposed by the film regulation agency of Chinese Government on imported foreign movies. For example, Kung Fu Panda 3, a co-production between Hollywood and Chinese studios, was permitted to play in Chinese theaters during the holiday block-out period of Chinese Lunar New Year (usually around and in February) (“China's Film Industry", 2016).

Co-production allows Hollywood studios to claim 43 percent of the film's box-office revenue in China (Brzeski \& Roxborough, 2017; O'Connor \& Armstrong, 2015), which is higher than the 25 percent for revenue-sharing imported movies. However, co-production has not yet become a popular option for large Hollywood studios and their blockbusters. Iron Man 3 and Transformers 4 were planned originally as Hollywood-China co-productions, but the Hollywood studios felt the production restrictions were burdensome and not worth potential benefits (Brzeski \& Roxborough, 2017). Marvel studios spent unprecedented time and effort trying to meet the requirements of state-run China Film Co-production 
Corporation (CFCC) and the State Administration of Press, Publication, Radio, Film and Television (SAPPRFT) in shooting Iron Man 3, and official censors visited the shooting set regularly and made suggestions to the script, but Iron Man 3 still failed to meet the co-production condition and ultimately was released as an imported revenue-sharing film in China (Kokas, 2017). Hollywood movies like Iron Man 3, which originally got co-production approval but could not complete the co-production process and were eventually released as an imported revenue-sharing film, are considered as faux-productions (Kokas, 2017).

Co-productions also have box-office uncertainties. So far, no co-produced movies, small or big, have achieved box-office success in both the U.S. and the Chinese cinema markets (Brzeski \& Roxborough, 2017). For example, the HollywoodChina co-produced movie The Flowers of War grossed $\$ 95$ million in China but only $\$ 311,000$ in the U.S. market; The Great Wall, a co-production, was a box-office disaster in both China and the U.S. and lost more than $\$ 75$ million (Brzeski \& Roxborough, 2017).

Despite the production restrictions and box-office uncertainties, co-production may turn out to be a good opportunity for small or newly-established Hollywood studios to enter the China's cinema market. Small and new studios need to compete with large film studios to survive. Instead of competing with Hollywood conglomerates in the U.S. market only, small studios may seek opportunities in China's growing market. It could be difficult for small studios to have their low-budget movies exported to China and be part of the 34 revenue-sharing foreign films that are mostly large-production blockbusters. However, small studios can make their movies co-productions, bypass the 34 -film import quota, and receive box-office revenues in China. Some small and new studios have already made co-production deals. For example, STX Entertainment, founded in 2014, will co-produce 18 films with Huayi Brothers Media, a Chinese media company ("China's Film Industry", 2016). Small and new studios may not have as much pressure as large studios do in terms of box-office performance. Even though a small studio's co-produced movie does not do well in the U.S. market, it may gross enough in China to make a decent profit since it can receive 43 percent of the film's total Chinese box-office revenue.

\subsection{Revenue-Sharing Films}

Exporting films to China as revenue-sharing titles is probably the most popular and preferred option for Hollywood studios to receive extra revenue in China's film market. Under the current film importation agreement, Hollywood studios can take 25 percent of the box-office revenue that the imported revenue-sharing Hollywood films receive in China (Frater, 2017; O'Connor \& Armstrong, 2015). Usually, those revenue-sharing foreign films that are imported by China are bigbudget blockbusters produced by the big six studios of Hollywood: Walt Disney, Warner Bros, Paramount, Fox, Sony, and Universal (Papish, 2017).

Some Hollywood revenue-sharing films have achieved box-office success in China's film market. For example, in 2014, Transformers: Age of Extinction made $\$ 320$ million box office revenue in China (Coonan, 2014a). In 2015, the ticket sales of Furious 7 in China reached $\$ 390$ million and surpassed the $\$ 349.3$ million box-office gross in North America (Verrier, 2015). In 2017, The Fate of The Furious (i.e., Fast \& Furious 8) made $\$ 393$ million in China's market and became by far the highest-grossing foreign film in China (Tartaglione, 2017).

Despite these successful cases of revenue-sharing films, Hollywood studios are facing huge pressure in China's film market. Only a limited number of foreign films (i.e., 34 films) can be imported as revenue-sharing titles each year, and the 34 imported-film spots are not exclusively reserved for Hollywood movies. Other foreign nations' films can also be imported by China. For example, in 2014, China imported 32 of the 34 revenue-sharing movies from Hollywood, one from Korea, and one from Europe (O'Connor \& Armstrong, 2015). In addition, not all the imported Hollywood films had successful box-office performance in China in the past, and some films such as Power Rangers and King Arthur: Legend of the Sword only had a moderate box-office gross in China (Barnes, 2017). Moreover, in recent years, China has been able to limit and control Hollywood films' share of China's annual total box office to around 40 percent through specific protectionist regulations and cultural policies such as import quota, blackout periods, short promotion window, and stacked-up releases (Frater, 2017). Indeed, compared to their 45.5 percent box-office market share in China in 2014, Hollywood films' market share dropped to 38.4 percent in 2015 and to 41.7 percent in 2016 (Brzeski, 2015; Brzeski, 2017). To encounter and resolve these challenges, Hollywood studios have taken necessary actions to secure their revenuesharing films' success in China through film localization efforts.

\section{Hollywood Film Localization for China's Film Market}

Since the box-office performance of revenue-sharing films matters a lot to Hollywood studios financially, it is crucial for Hollywood studios to take actions proactively to foster their roles as participators in China's film market and to prove Hollywood films' economic value to China. Hollywood studios have made various efforts to localize their films by incorporating certain China-focused techniques and strategies in order to appeal to China's market. The localization efforts of Hollywood studios are prevalent and executed in every stage of a film theatrical life cycle, from the film planning and production stages to the distribution, promotion, and exhibition stages. The following review identifies the specific 
localization efforts that Hollywood studios have made, provides the context for implementation, and demonstrates the effects and outcomes of those efforts by presenting real-world examples, factual evidence, and research findings extracted from the literature.

\subsection{Localization Efforts for Film Planning and Production}

Hollywood studios have been producing and exporting genres of films that Chinese audiences generally prefer. Science fiction, alien invasion, catastrophes, space travel, horror, and super heroes are identified as the major, longstanding themes of Hollywood blockbusters (Aknin, 2012). However, action blockbusters (Guo, 2005) and large-scale science-fiction movies are preferred by Chinese audiences (Kwak \& Zhang, 2011). In addition, 3D-effect foreign films are also liked by Chinese audiences (Kwak \& Zhang, 2011). China's annual import quota of foreign films was increased from 20 to 34 in 2012 (Kokas, 2017), and the added 14 movies were to be in special 3-D or IMAX format (Kokas, 2017). The increased quota provides Hollywood studios the opportunity to produce more promising action and science-fiction movies in 3-D or IMAX format to export to China.

Given that animation films have been doing quite well in China (Swanson, 2015), Hollywood studios have produced and exported several animation blockbusters to China in recent years. For example, Zootopia and Finding Dory had very good box office gross in China, which helped both movies be among the most profitable films globally in 2016 (Robinson, 2016). Indeed, Chinese audiences enjoy animation productions as family films, which provides a good opportunity for Hollywood since those films can be easily dubbed into Chinese language (Robinson, 2016; Swanson, 2015) and have relatively simple story lines (Swanson, 2015). Animation movies usually come with 3-D versions, which is also a big attraction for Chinese audiences.

Hollywood studios have been including Chinese elements in their films to reduce cultural differences and generate familiarity for Chinese audiences. Contemporary Hollywood movies have become less traditionally American (Lee, 2008). Many Hollywood movies achieve success by incorporating themes and motifs from other cultures and countries (Crane, 2014). In response to the Chinese critics' decade-long concerns that Hollywood movies promote and propagate American cultures, values, and way of life (Crane, 2014; Su 2011), Hollywood studios have been making attempts to somewhat localize their productions by including Chinese elements to fit Chinese culture. When seeing Chinese elements in a Hollywood movie, Chinese audiences generally would feel comfortable and proud (Chen, 2009; Kwak \& Zhang, 2011). Research also shows that including Chinese elements in a Hollywood film is positively related to the film's box-office performance in China (Kwak \& Zhang, 2011). Gravity presented the Chinese space-station and space program in a positive light and grossed $\$ 71$ million (i.e., 10 percent of the film's total worldwide box-office gross) in China (O'Connor \& Armstrong, 2015). In some movies, the Chinese elements are placed subtly. For example, the newscaster in the U.S. version of Zootopia is a moose, but Disney changed it to a panda in the movie's Chinese version to help Chinese audiences connect with the movie (Libbey, 2016). In other movies, the elements are included explicitly and quite recognizable. $X$ Men: Days of Future Past included scenes in Hong Kong and grossed \$116 million in China (O'Connor \& Armstrong, 2015). Sometimes, even though Chinese elements were difficult to be included in a movie, studios would find some way to link the movie to China. For example, when Avatar was promoted in China, it was advertised that the "tree" in the movie and what it symbolized were conceptualized from Chinese culture (Kwak \& Zhang, 2011).

Hollywood studios have cast Chinese talents in the blockbusters that they plan to export to China. It is reported that Chinese stars' participation in a Hollywood movie is positively related to the film's Chinese box-office performance (Kwak \& Zhang, 2011). Indeed, compared to other efforts Hollywood studios have made in their revenue-sharing collaborations with China, casting Chinese stars in a movie is often an easier approach (Kokas, 2017). Including Chinese talents in a Hollywood film production is a good investment for Hollywood studios, for the Chinese stars could help promote Hollywood films in China, draw local media's attention, and raise the favorable expectations of Chinese movie goers.

Hollywood studios have also collaborated with Chinese investors by placing their products in films. As some Chinese investors provide production budgets and invest in Hollywood films, collaboration between Hollywood studios and Chinese investors has increased (Kokas, 2017). However, in some China-Hollywood collaborated movies, the Chinese products were awkwardly inserted into the film and forced into the narrative (Kokas, 2017). For example, Chinese audiences complained about awkward product placements in Transformers 4 and some even felt disgusted at seeing so many product placements in a movie (Kuo, 2014). Independence Day: Resurgence placed a Chinese milk company's product in the movie, but the placement was awkwardly inserted, and the film was accused of pandering (Robinson, 2016). It appears that Hollywood studios need to figure out how to properly place their Chinese investors' products in the films.

\subsection{Localization Efforts for Film Distribution, Promotion, and Exhibition}

To ensure the films that Hollywood studios intend to export would pass the Chinese regulators' censorship and receive distribution and screening approval, Hollywood studios have been adapting to the censorship requirements of China's 
film regulation agency (i.e., previously SAPPRFT; now the Department of Propaganda) by localizing and modifying their blockbusters to create the Chinese versions of revenue-sharing films. China has its own cultural policies for importation of cultural products. One of China's cultural policies to protect its own film industry is to establish strict import quotas for Hollywood and foreign films (Crane, 2014). Chinese film regulation agency oversees and regulates the contents of imported films distributed in China and "all films exported to China must adhere to the principles of the Chinese Constitution and maintain social morality" (O'Connor \& Armstrong, 2015, p. 9). Films that present anti-China content, from merely damaging a Chinese city to denigrating Chinese government and authority, would be prohibited and banned (O'Connor \& Armstrong, 2015; Vittachi, 2015). For example, Sony studio deleted scenes from the 2015 movie Pixel in which aliens attacked and damaged the Great Wall of China just to increase the movie's chances to be screened in China (Swanson, 2015).

To acquire a wide distribution for their films, Hollywood studios have been closely collaborating with the Chinese film distributors. Universal Pictures partnered with a Chinese film distribution company, China Film Group, and secured a wide distribution for Furious 7 in China by sharing a portion of the film's revenue with the distributor (Qin, 2015). As a result, the film achieved a huge box office success in China (Qin, 2015). Wide theatrical distribution may not affect Chinese audience's satisfaction with a movie (Sussan \& Chinta, 2016), for movie goers would enjoy a high-quality production even though it is not played in many theaters. However, wide distribution increases the number of screenings a film receives per day, which potentially results in more viewers per day and helps the movie achieve higher box office gross within the same length of distribution period.

Hollywood studios have requested special opening days for their blockbusters to be exhibited in China's theaters to accommodate Chinese movie goers and to boost those films' box office performance. For Hollywood films in China, research shows that timing the release around China's peak seasons is positively related to the box-office performance (Kwak \& Zhang, 2011). Different from the peak seasons for releasing films in the United States which are around Thanksgiving Day, Christmas Day, New Year's Day, and other national holidays (Cooper-Martin, 1992), the peak seasons in China are considered to be around holidays when the Chinese family gathers (e.g., National Establishment Day, midautumn festival, etc.) (Kwak \& Zhang, 2011). For example, Hollywood studios secured an unusual (a Sunday) but propitious opening (April 12th) for Furious 7 to be exhibited in China, which helped the film set China's new record for an opening-day box office (Cunningham, 2015) and the opening was followed by the peak season of the May Day holiday (i.e., Labor Day holiday) starting on May 1st, which extended the movie's success.

To promote their revenue-sharing films and attract local media attention in China's cinema market, Hollywood studios have arranged promotional events in major cities of China and sent film directors, producers, and main cast to China to participate in promotional activities. Paramount Pictures arranged two red-carpet premiere events in Beijing and Shanghai and the world premiere in Hong Kong for Transformers: Age of Extinction with the participation of the main crew and cast (Jenkins, 2014; Schwartzel \& Burkitt, 2014). The main cast of Furious 7 attended a press conference in Beijing prior to the opening to promote the film, and the event was heavily covered by Chinese local media (Cunningham, 2015). At other promotion media events, the Hollywood movie director, producer, and the cast members also have praised the Chinese star's contribution to the movie and expressed their gratitude to Chinese audiences. For example, at a media event in Shanghai, Mark Wahlberg, the leading actor in Transformers: Age of Extinction, suggested that he and the Chinese actress Lin Bingbing, who played a role in the movie, should play a couple in the next Transformers film (Yang, 2014). Director Michael Bay shared with the media that the people of the city were great and impressed him the most (Jenkins, 2014).

\section{Implications and Suggestions for Hollywood's Further Localization Efforts}

The film localization efforts of Hollywood studios mentioned above have, more or less, supported Hollywood films' boxoffice performance in China. It is obvious that Hollywood studios have become especially attentive to China's film market due to its economic importance and potential. As the collaborations between Hollywood and China continuously increase in the coming years, Hollywood studios need to explore and implement further efforts in terms of film localization in order to secure and extend their revenue-sharing films' success in China's film market. This section reviews the current trends and influential factors related to Hollywood films in China, provides implications and suggestions accordingly, and explains the rationales by integrating film studies' research findings and real-world case evidence into the discussion.

Because films collaborated between China and Hollywood show contemporary China to the world (Kokas, 2017), Hollywood studios should check whether the film narrative and storyline portray China positively. This could help the movie leave a good impression on Chinese regulators and increase the movie's chance for being approved for screening in China. Some movies have already tried this technique. For example, Transformers 4 depicts the authoritarian styles of Chinese government positively in the movie (Coonan, 2014b) and presents the Chinese Ministry of Defense in a favorable way (Kokas, 2017). 
If appropriate, Hollywood studios may consider casting Chinese talents in major roles. For example, Disney cast the Chinese actress Liu Yifei to star as the legendary Chinese warrior Mulan in the live-action version of its movie Mulan (Saad, 2017). This casting decision to use a Chinese actress for the major role was influenced by the storyline. However, Hollywood studios do not necessarily need to cast Chinese actors/actresses for leading roles to appeal to Chinese audiences and please their fans, unless the movie storyline requires it. In many cases, supporting roles played by Chinese actors/actresses would be sufficient to help the film attract Chinese movie goers.

When casting Chinese talents, Hollywood studios may need to carefully evaluate whether the Chinese actor/actress has the ability to play the role. One consideration is the individual's English language ability. Language is the most obvious challenge faced by actors/actresses and other above-the-line players such as directors and writers in a transnational movie production (Kokas, 2017). If the Chinese cast cannot understand the director's instructions due to language barrier, Hollywood studios should hire a competent language interpreter to assist the cast understand the instructions. Linguistic interpreters are essential to the cross-cultural filmmaking process (Kokas, 2017). Interpreters and other below-the-line bicultural workers not only bridge the cultural gaps between film workers from China and Hollywood, but also create vital connections, smooth the interactions, navigate negotiations within productions, and facilitate production activities on the set (Kokas, 2017).

Since Hollywood transnational movies are filmed in English (Vanderschelden, 2007), Hollywood studios may need to assign fewer speaking lines to a Chinese actor or actress whose English speaking ability is not proficient. In addition to pleasing the Chinese audiences, Hollywood studios should also consider the Northern American and other global audiences' movie viewing enjoyment and satisfaction. If the English of the Chinese cast is difficult to understand, it may distract American and other English-speaking audiences from following the storyline and decrease their satisfaction with the movie. For example, when Gong Li, a famous Chinese actress, played the leading role in Miami Vice, her speaking English was perceived as often incomprehensible (Bonawitz, 2006). Ideally, Hollywood studios should cast a Chinese star whose English is understandable. If the movie storyline requires the Chinese cast to speak a lot on screen, studios may hire a language coach to correct and improve the Chinese cast's English pronunciation.

Hollywood studios need to understand that including Chinese casts in a movie may not immediately help the movie become a huge success in China, especially for some franchise series that the Chinese audiences are not familiar with. Star Wars: The Force Awakens did not perform as well as Disney and Lucasfilm had expected: it only grossed $\$ 124.2$ million in China compared to its $\$ 2$ billion global gross (Robinson, 2016). Although a $\$ 120$ plus box office gross in China is not bad, it pales compared to the movie's global gross. For the next franchise installment, Rogue One: A Star Wars Story, the studios cast two well-known Chinese stars, Donnie Yen and Jiang Wen, hoping this Chinese talent inclusion could help Chinese audiences relate to the movie (Leadbeater, 2017). However, casting the two actors did not give this Star Wars installment the boost expected (Leadbeater, 2017). According to boxofficemojo.com, Rogue One grossed $\$ 69.5$ million in China compared to $\$ 1.06$ billion worldwide. According to some news reports, movie industry insider and analyst Jonathan Papish gave several possible reasons for the movie's poor reception in China: original Star Wars movies and prequels were not released in China, and consequently generations of Star Wars movie fans do not exist in China; the general Chinese audiences are unfamiliar with the stories and characters, and the newer generation of Chinese movie goers do not care about the stories; fans of Donnie Yen and Jiang Wen watched the movie to see their faces but were completely confused or bored with the store line (Leadbeater, 2017).

Even though including Chinese actors did not make Rogue One: A Star Wars Story gross more than Star Wars: The Force Awakens in China, Rogue One movie's China's box-office share of the global gross is slightly higher than that of The Force Awakens. Based on the data provided by boxofficemojo.com, Rogue One: A Star Wars Story's China's box office was 6.58 percent of its global gross, while Star Wars: The Force Awakens' China's box office was only 6.00 percent of its global gross. This small increase of the box-office share may seem trivial, but it is a good start for a franchise like Star Wars that relies on the support of an enormous fan base to enter China's cinema market and receive additional box office revenue. Given that the Star Wars:The Force Awakens movie was not really angled towards the Chinese audience (Robinson, 2016) and both movies are huge success for Disney and Lucasfilm in terms of global box-office gross (Leadbeater, 2017), Chinese stars' appearance in the movie was a good experimental attempt to start cultivating Chinese fans for the franchise.

As Song (2018) suggests, "Chinese component should be integrated in the movie in a smooth and seamless way" (p. 185). As for product placement, studios need to consider where and when a product should be shown in the movie so that it can be easily recognized by Chinese audiences but will not be negatively perceived by the audiences or disrupt the film's storyline. Media production in China is relationship dependent (Kokas, 2017), and Hollywood studios and their "compradors" (i.e., above-the-line players) should accustom themselves to this fact and be able to coordinate the different expectations of film collaborative partners (Kokas, 2017). Hollywood studios should honor the product placement agreement that they have made with their Chinese business partners to avoid an unexpected crisis (Song, 2018). Failing 
to meet the agreement's terms may risk a film's distribution in China. For example, when Pangu, one of the Paramount's Chinese investors, did not get the 20-second appearance for its hotel in Transformers 4 as the product-placement agreement promised, it threatened to delay the film's release in China and planned to file a lawsuit against the studio just about one week before Transformers 4 film's global launch (Makinen, 2014). To resolve this unexpected crisis and dispute and secure the film's Chinese release date, Paramount vice chairman as well as the movie's director and producer rushed to Beijing to reconcile with Pangu (Makinen, 2014). The last-minute negotiation worked: Pangu decided to not file the lawsuit which would have postponed the movie's opening in China, and thus Paramount avoided the loss of millions by releasing the movie as scheduled (Makinen, 2014).

If studios make deals with Chinese investment partners through a middleman, studios need to review the terms of a contract carefully and communicate directly with both the middleman and the investors to reach an understanding. Product-placement deals made through third-party agencies could complicate communications, lose information in translation, and cause misunderstanding (Kuo, 2014). If some terms are difficult to honor, studios may negotiate with the investor or consider dropping the deal to avoid potential setbacks. Paramount could have avoided the Transformers 4 disputes if it had directly communicated with the Chinese investors to clarify the terms before the movie shooting was completed. Two middlemen companies, Jiaflix and Chengxin, set up the Pangu's product-placement contract with Paramount; however, Paramount and Pangu had a misunderstanding about the deal and Pangu's executive felt they were being cheated (Makinen, 2014). A similar misunderstanding happened to Paramount and another Chinese partner, Wulong tourism company. Wulong claimed that its logo was not shown in the movie, while the U.S. production team thought the sign with Chinese characters was the logo (Kuo, 2014). This demonstrates the importance of having bicultural below-theline workers in the production crew. The bi-cultural below-the-line film setting and logistics workers manage the cultural and spatial translation, and their roles are crucial in the cross-cultural filmmaking process and in the China-Hollywood production ecosystem (Kokas, 2017).

Hollywood studios need to comply with China's cultural policy and try to obtain the screening approval for their blockbusters before the import quota is reached in China. Although research shows Hollywood movies dominate the top10-film lists both in the global market and in many countries' national markets (Crane, 2014), it does not mean Hollywood movies have no competition. China's reinforcement of the import quota on foreign films creates a tough competition environment for Hollywood studios (Swanson, 2015). For example, the increase of ticket sales for Hollywood movies was only 1.7 percent in the first six months of 2017 over the same period of 2016, but ticket sales for all the imported foreign films actually increased 35 percent in China (Barnes, 2017).

For blockbusters that have box-office potential but contain scenes and themes that may not pass the Chinese regulators' censorship, Hollywood studios need to be willing to make changes to the films to secure the import deals with China. Hollywood studios could strategically whitewash their films by avoiding political topics like Tibet and not depicting Chinese people as villains (Kokas, 2017). Since there is still no film rating and classification system in China's film market (Lang \& Frater, 2018), Hollywood studios should make sure that the contents of films that they intend to export to China are appropriate to all age groups of audiences. Hollywood studios should try to eliminate inappropriate language and excessive violence and indecency from their revenue-sharing films, for those kinds of contents are generally prohibited by Chinese film regulators (Langfitt, 2015).

Sometimes even after the import quota is reached, Hollywood studios may want to constantly monitor China's box office performance and actively seek an import deal. The reason is that although the stated annual import quota is 34, Chinese regulators may at times allow more than 34 revenue-sharing foreign films to be imported (Frater, 2017). For example, in 2016 China imported 40 revenue-sharing movies, instead of 34, to boost the cinema market after experiencing an unexpected box-office downturn (Frater, 2017). If China's overall box office growth is not as prominent as expected, Chinese regulators may increase the number of imported films at the end of the year and Hollywood studios could then seize the opportunity to send more titles through the screening approval process and export additional revenue-sharing films.

Hollywood studios could send their C-suite executives and other above-the-line decision-makers to China-US film industry forums, film festivals, and film markets to interact with Chinese policy makers and industry leaders to promote Hollywood movies and seek production and distribution deals (Kokas, 2017). Although participating in such events may not immediately secure any promotion and distribution deals, Hollywood studios can take these opportunities to cultivate relations with China's main players in the film industry, share each others' stories, understand each others' expectations, and express intentions to further collaborations (Kokas, 2017).

Hollywood studios may expect more frequent and closer collaborations with the Chinese distributors and film promotion partners in coming years. Hollywood studios need to cooperate strategically with Chinese distributors to increase the playability of their movies in China. In China, Hollywood studios are required to partner with Chinese distribution 
companies and are not allowed to independently promote and distribute their films (Mayyasi, 2016; "The CFI guide to film production", n.d.). China Film Group and Huaxia Film Distribution are the two state-owned film distribution agencies that distribute foreign films in China (Kwak \& Zhang, 2011). These two film distributors network with Chinese government regulators to distribute foreign movies and sometimes may even disagree with the government regulators on which movie to distribute (Kwak \& Zhang, 2011). China Film Group and the China's Film Bureau work together to determine the release dates of foreign films (Frater, 2017), the blackout periods during which no foreign films are released (Frater, 2013), and the weeks in which multiple foreign films are stack-released to compete with each other (Frater, 2013).

Hollywood studios also need to collaborate proactively with Chinese promotion partners to prepare promotional materials and events within a very short period of time. The reason is Hollywood studios usually would only be notified by China's Film Bureau/China Film Group four to six weeks prior to their revenue-sharing films' China's release dates (Frater, 2017). Hollywood studios' marketing campaigns are dramatically affected and limited by the short-time notice (Frater, 2017). Given that Chinese movie viewers are reported to be more responsive to movie stars than to film directors (Kwak \& Zhang, 2011), Hollywood studios and their Chinese promotion partners may consider focusing less on the directors and more on the Hollywood stars and Chinese cast when promoting films in China. In addition, a studio's marketing teams should use digital communications tools such as social media and online reviews to monitor and share peer attitudes toward their films (Sussan \& Chinta, 2016). Hollywood studios should strategically use digital media to promote their films in China. For example, studios can use Mtime, a Chinese film database website integrated with film news, reviews, and online ticket sales, to promote films to the new generations of Chinese audiences (Barnes \& Qin, 2015).

Hollywood studios should also make good use of the movie consumers' online reviews in China. Although movie marketing strategies and activities are usually determined and executed before a movie is released (Sussan \& Chinta, 2016), consumer peer reviews can offer the studios the opportunity to continue promoting the film after the film is launched. A consumer's choice of which movies to watch is often influenced by peer evaluations of the movies, which in turn might be influenced by the evaluations of media critics and other peers (Koh, Hu, \& Demons, 2010; Sussan \& Chinta, 2016). Studios may share the favorable reviews of movie consumers on social media and online forums and with local media to encourage more people to watch movies in the theater. Indeed, research shows that social influence can mediate the studio's marketing efforts and Chinese customer satisfaction with a film (Sussan \& Chinta, 2016).

\section{Conclusion}

Research on the dynamics between Hollywood films and China's film market remains an interesting topic in academia and continues to draw attention from global researchers of film studies. As the film market in China has grown dramatically in recent years, Hollywood studios have prioritized their global film marketing strategies for China. This research reviews the approaches that Hollywood studios have used to send their films to China and the film localization efforts that the studios have made to appeal to China's film market. Implications and suggestions are provided on how Hollywood studios may further their localization efforts to secure and boost their films' success in China's film market. Exemplary evidence, facts, data, and research findings extracted from the literature are synthesized and used in the present study to support the review findings and the study's proposed implications and suggestions, while answering the research questions.

To receive additional revenues from China's booming film market, Hollywood has been sending a significant number of films to China as flat-rate buyouts, co-productions, and revenue-sharing titles. Although flat-rate buyouts and coproductions can bring extra revenues for Hollywood studios, they are not popular options due to limited benefits and complicated restrictions. Exporting revenue-sharing films has become the favorite approach for Hollywood studios to receive additional revenues in China's film market. However, only a limited number of revenue-sharing foreign films are imported by China to screen in theaters every year. Hollywood studios have thus made China-focused localization efforts throughout a film's theatrical life cycle to improve their revenue-sharing films' chance for screening approval and to increase their films' box office revenues in China. Because China's film market keeps growing and more revenue-sharing foreign films may be imported by China in the future, Hollywood studios should consider exploring more strategies and techniques to further localize their revenue-sharing films to appeal to China. 


\section{References}

Aknin, L. (2012). Mythes et idéologie du cinéma américain [Myths and ideology in American cinema]. Paris: Vendémiaire. https://doi.org/10.14375/NP.9782363580313

Barnes, B. (2017). China's softening ticket sales are drawing Hollywood's focus. Retrieved from https://www.nytimes.com/2017/07/13/business/media/hollywood-china-box-office.html

Barnes, B., \& Qin, A. (2015). Mtime helps Hollywood clear china's marketing hurdles and reach fans. Retrieved from http://www.nytimes.com/2015/08/10/business/mtime-helps-hollywood-clear-chinas-marketing-hurdles-and-reachfans.html?partner=bloomberg

Bonawitz, A. (2006). 'Miami Vice' plays it straight. Retrieved from https://www.cbsnews.com/news/miami-vice-plays-it-straight/

Brzeski, P. (2015). China box office grows astonishing 48.7 percent in 2015, hits $\$ 6.78$ billion. Retrieved from $\mathrm{http} / / / \mathrm{www}$.hollywoodreporter.com/news/china-box-office-grows-astonishing-851629

Brzeski, P. (2017). China box-office growth slowed to 3.7 percent in 2016, official data shows. Retrieved from https://www.hollywoodreporter.com/news/china-box-office-growth-slows-37-percent-2016-official-data-shows960217

Brzeski, P. (2018). China box office returns to robust growth in 2017, hitting \$8.6B. Retrieved from https://www.hollywoodreporter.com/news/china-box-office-returns-robust-growth-2017-hitting-86b-1070895

Brzeski. P., \& Roxborough, S. (2017). After 'The Great Wall,' can China-Hollywood co-productions be saved? http://www.hollywoodreporter.com/news/great-wall-can-china-hollywood-productions-be-saved-1005240

Chen, L. (2009). Cultural implications about analysis of factors to go watching "Kung Fu Panda." Shanxi Community College Journal, 1, 55-75.

Child, B. (2012). China will be the world's biggest film market by 2020. Retrieved from https://www.theguardian.com/film/2012/nov/29/china-biggest-film-market-2020

China's Film Industry: A blockbuster in the making.Knowledge@Wharton. (2016). Retrieved from http://knowledge.wharton.upenn.edu/article/lights-china-action-how-china-is-getting-into-the-global-ntertainmentbusiness/

Coonan, C. (2014a). China box office 2014: 'Transformers 4,' homegrown films on top. Retrieved from http://www.hollywoodreporter.com/news/china-box-office-2014-transformers-760374

Coonan, C. (2014b). China box office: 'Transformers: Age of Extinction' is No. 1 film of all time. Retrieved from http://www.hollywoodreporter.com/news/transformers-age-extinction-becomes-chinas-717083

Cooper-Martin, E. (1992). Consumers and movies: Information sources for experiential products. Advance in Consumer Research, 19(1), 756-761.

Crane, D. (2014). Cultural globalization and the dominance of the American film industry: cultural policies, national film industries, and transnational film. International Journal of Cultural Policy, 20(4), 365-382. https://doi.org/10.1080/10286632.2013.832233

Cunningham, T. (2015). 'Furious 7's'massive China haul will exceed its U.S. box office. Retrieved from http://fortune.com/2015/04/28/furious-7s-massive-china-haul-will-exceed-its-u-s-box-office/

Frater, P. (2013). Enter the Dragon. Variety, 321(10), 34-39.

Frater, P. (2017). Hollywood muscle props China's summer box office. Variety, 336(14), 20.

Guo, Z. (2005). Jackie Chen: Neverending Spirit of a Hero. Films, 1, 14-15.

Jenkins, N. (2014). The latest Transformers has its world premiere in Hong Kong. Retrieved from http:/time.com/2903983/the-latest-transformers-has-its-world-premiere-in-hong-kong/

Koh, N. S., Hu, N., \& Demons, E. K. (2010). Do online reviews reflect a product's true perceived quality? An investigation of online movie reviews across cultures. Electronic Commerce Research and Applications, 9(5), 374-385. https://doi.org/10.1016/j.elerap.2010.04.001

Kokas, A. (2017). Hollywood made in China. Oakland: University of California Press.

Kuo, L. (2014). Transformers 4 and the perils of backfiring product placement. Retrieved from https://www.theatlantic.com/entertainment/archive/2014/07/how-chinese-product-placement-blew-up-in-the-faceof-transformers/374236/ 
Kwak, J., \& Zhang, L. (2011). Does China love Hollywood? An empirical study on the determinants of the box-office performance of the foreign films in China. International Area Studies Review, 14(2), 115-140. https://doi.org/10.1177/223386591101400205

Lang, B., \& Frater, P. (2018). China film quota talks could be a casualty in Trump's trade war. Retrieved from https:/variety.com/2018/film/news/china-film-quota-hollywood-trump-trade-war-1202739283/

Langfitt, F. (2015). How China's censors influence Hollywood. Retrieved from http://www.npr.org/sections/parallels/2015/05/18/407619652/how-chinas-censors-influence-hollywood.

Leadbeater, A. (2017). Why Star Wars still struggles at the Chinese box office. Retrieved from https://screenrant.com/star-wars-chinese-box-office/

Lee, F. L. F. (2008). Hollywood movies in East Asia: Examining cultural discount and performance predictability at the box office. Asian Journal of Communication, 18(2), 117-136. https://doi.org/10.1080/01292980802021855

Libbey, D. (2016). The one character Zootopia changed for international audiences. Retrieved from https://www.cinemablend.com/new/One-Character-Zootopia-Changed-International-Audiences-116847.html

Makinen, J. (2014). Paramount rushes to end 'Transformers' dispute in China. Retrieved from http://www.latimes.com/entertainment/envelope/cotown/la-et-ct-china-paramount-transformers-20140624story.html

Mayyasi, A. (2016). How Hollywood changes movies to appease foreign censors. Retrieved from https://priceonomics.com/hollywoods-new-chinese-censors/

O’Connor, S., \& Armstrong, N. (2015). Directed by Hollywood, edited by China: How China's censorship and influence affect films worldwide. Retrieved from

https://www.uscc.gov/Research/directed-hollywood-edited-china-how-china\%E2\%80\%99s-censorship-andinfluence-affect-films-worldwide

Papish, J. (2017). Foreign films in China: how does it work? Retrieved from http://chinafilminsider.com/foreign-films-in-china-how-does-it-work/

Qin, A. (2015). 'Furious 7'becomes China's most successful movie ever. Retrieved from http://sinosphere.blogs.nytimes.com/2015/04/29/furious-7-becomes-chinas-most-successful-movie-ever/?_r=0

Robinson, J. (2016). China wins Hollywood: Did you catch all the ways Hollywood pandered to China this year? Retrieved from

https://www.vanityfair.com/hollywood/2016/08/did-you-catch-the-ways-hollywood-pandered-to-china-this-year

Saad, N. (2017). Chinese actress Liu Yifei to star as title character in Disney's live-action Mulan. Retrieved from https://www.thestar.com/entertainment/movies/2017/11/30/chinese-actress-liu-yifei-to-star-as-title-character-indisneys-live-action-mulan.html

Schwartzel, E., \& Burkitt, L. (2014). Lights! Camera! China! 'Transformers' knows its audience. Retrieved from http://www.wsj.com/articles/for-transformers-audience-action-is-in-china-1403805965

Song, X. (2018). Hollywood movies and China: Analysis of Hollywood globalization and relationship management in China's cinema market. Global Media and China, 3(3), 177-194. https://doi.org/10.1177/2059436418805538

$\mathrm{Su}$, W. (2011). Resisting cultural imperialism, or welcoming cultural globalization? China's extensive debate on Hollywood cinema from 1994 to 2007. Asian Journal of Communication, 21(2), 186-201. https://doi.org/10.1080/01292986.2010.539301

Sussan, F., \& Chinta, R. (2016). Converging and diverging forces on customer satisfaction: Comparative empirical analysis of hollywood movies in the U.S. and china. S.A.M. Advanced Management Journal, 81(2), 31-44.

Swanson, A. (2015). Stephen Colbert's "Pander Express" is a brilliant takedown of how Hollywood sucks up to China. Retrieved from

https://www.washingtonpost.com/news/wonk/wp/2015/10/10/stephen-colberts-pander-express-is-a-brillianttakedown-of-how-hollywood-sucks-up-to-china/?utm_term=.83e0b66e 9695

Tartaglione, N. (2017). China box office tops $\$ 7.5$ b milestone; admissions up 15\% so far in 2017. Retrieved from http://deadline.com/2017/11/china-box-office-record-7-5-billion-dollars-50-billion-yuan-1202212987/

The CFI guide to film production in China. (2016). Retrieved from http://chinafilminsider.com/cfi-guide-10-things-know-working-film-china/

Vanderschelden, I. (2007). Strategies for a 'transnational'/French popular cinema. Modern and contemporary France, 
15(1), 37-50. https://doi.org/10.1080/09639480601115276

Verrier, R. (2015). Box office in China is soaring to new highs. Retrieved from http://www.latimes.com/entertainment/envelope/cotown/la-et-ct-china-films-box-office-20150604-story.html

Vittachi, N. (2015). China's Crime-Free Crime Films. Retrieved from https://www.nytimes.com/2015/01/04/opinion/sunday/chinas-crime-free-crime-films.html

Xin, H. (2017). China to be world's largest film market by 2020. Retrieved from http://www.chinadaily.com.cn/business/2017-08/30/content_31328301.htm

Yang, Y. Y. (2014). Transformers 4 main cast arrives Shanghai. (In Chinese). Retrieved from http://www.chinanews.com/tp/hd2011/2014/06-22/365021.shtml

\section{Copyrights}

Copyright for this article is retained by the author(s), with first publication rights granted to the journal.

This is an open-access article distributed under the terms and conditions of the Creative Commons Attribution license (http://creativecommons.org/licenses/by/4.0/). 